\author{
An-Nur: Jurnal Studi Islam \\ P-ISSN 1829-8753 - E-ISSN 2502-0587 \\ Vol. 13 No. 1 (January - June 2021) \\ Available at: https://jurnalannur.ac.id/index.php/An-Nur
}

\title{
STRATEGI PEMASARAN SEKOLAH BERBASIS PESANTREN
}

\author{
Nur Wahid Sugiyanto \\ UIN Sunan Kalijaga Yogyakarta \\ e-mail:nunrwahid99@gmail.com \\ Sedya Santosa \\ UIN Sunan Kalijaga Yogyakarta \\ e-mail: sedy.santosa@uin-suka.ac.id
}

\begin{abstract}
Abstrak
Penelitian ini bertujuan untuk mengetabuai strategi pemasaran jasa pendidikan di MA Al-Ma'bad An-Nur, serta mengetahui faktor pendukung, penghambat serta solusi yang ditawarkan peneliti yang berkaitan dengan terselenggaranya pemasaran jasa pendidikan di MA Al-Ma'bad An-Nur. Penelitian ini merupakan penelitian kualitatif, dengan teknik wawancara, observasi, dan triangulasi. Analisa data menggunakan Miles dan Huberman. Hasil penelitian ini adalab: (1) Strategi Pemasaran jasa pendidikan di MA Al-Ma'bad AnNur dilaksanakan melalui penerapan Marketing MIX (produk, harga, tempat, promosi, sumber daya manusia, bukti fisik dan proses). (2) Penerepan Jasa Pendidikan di MA AlMa'bad An-Nur meliputi perencanaan, pengorganisasian, pengarahan, dan pengawasan.(3) faktor pendukung adalah sekolah yang terintegrasi antara kurikulum sekolah dan kepesantrenan. Faktor penghambat, sistem sekolah yang terintegrasi antara kurikulum sekolah dan pesantren belum berjalan secara total, disebabkan standar penerimaan peserta didik baru terlalu tinggi. Solusi yang ditawarkan peneliti adanya kelas pra $M A$ yang diperuntukan bagi peserta didik yang lulus seleksi, namun tidak atau kurang masuk kualifikasi standar penerimaan peserta didik baru.
\end{abstract}

Kata Kunci: Strategi pemasaran pendidikan, MA Al-Ma'had An-Nur

\begin{abstract}
This study aims to find out the marketing strategy of education services in MA Al-Ma'bad An-Nur, as well as to find out the supporting factors, obstacles and solutions offered by researchers relating to the implementation of education services marketing in $M A$ Al-Ma'bad An-Nur. This research is a qualitative research, with interview, observation, and triangulation techniques. Data analysis using Miles and Huberman. The results of this research are: (1) The strategy of educational services at MA Al-Ma'bad An-Nur Marketing is carried out through the application of Marketing MIX (product, price, place, promotion, human resources, physical evidence and processes). (2) Implementation of Educational Services at MA Al-Ma'bad AnNur including planning, organizing, directing and supervising. (3) the supporting factor is a school that is integrated between the school curriculum and the pesantrenan. The inbibiting factor is that the integrated school system between the curriculum and the pesantren has not run
\end{abstract}


completely, due to the high acceptance of new students. The solution offered by researchers was the pre-MA class which was intended for students who passed the selection, but did not or did not qualify for the admission of new students.

Keywords : education marketing strategy, $M A$ Al-Ma'bad An-Nur,

\section{A. Pendahuluan}

Pendidikan berfungsi mengembangkan kemampuan dan membentuk watak serta peradaban bangsa yang bermartabat dalam rangka mencerdaskan kehidupan bangsa. Sedangkan tujuan pendidikan untuk berkembangnya potensi peserta didik agar menjadi manusia yang beriman dan bertakwa kepada Tuhan yang Maha Esa, berakhak mulia, sehat, berilmu, cakap, kreatif, mandiri, dan menjadi warga negara yang demokrasi serta tanggung jawab. ${ }^{1}$

Pendidikan dewasa ini mengalami banyak perubahan yang sangat signifikan, hal tersebut dipicu oleh pengaruh global pendidikan, atau yang sering diistilahkan globalisasi pendidikan. Globalisasi melahirkan persaingan yang ketat dalam dunia pendidikan, lembaga pendidikan harus menjaga kualitas dan terus berinovasi agar tidak ditinggallkan masyarakat selaku konsumen pendidikan. Maka dari itu lahirlah paradigma pemasaran jasa pendidikan. Hadirnya paradigma pemasaran jasa pendidikan tidak dimaksudkan sebagai upaya komersialisasi pendidikan, namun lebih kepada strategi lembaga pendidikan, agar tetap eksis dalam merespon tantangan dan perubahan zaman yang terus tumbuh, berubah, dan berkembang. ${ }^{2}$

Pesantren atau pondok adalah lembaga yang bisa dikatakan merupakan wujud proses wajar perkembangan sistem pendidikan nasional. Dari segi historis pesantren tidak hanya identik dengan makna keislaman, tetapi juga mengandung makna keasilan Indonesia. ${ }^{3}$ Sejarah perjalanan pesantren telah teruji dari waktukewaktu berbagai perubahan sosial, politik, dan ekonomi telah dilewati pesantren. Dahulu pesantren hanya mengajarkan ilmu-ilmu agama dengan cara mendirikan

\footnotetext{
${ }^{1}$ Pasal 3 Undang-Undang No 20 Tahun 2003 Tentang Pendidikan Nasional

${ }^{2}$ Syahrial Labaso "Penerapan Marketing Mix Sebagai Pemasaran Jasa Pendidikan di MAN 1 Yogyakarta"dalam Manageria : Jurnal Manajemen Pendidikan Islam, Vol. 3, Nomor 2, November 2018), 291

${ }^{3}$ Nurcholish Madjid, Bilik-Bilike Pesantren Sebuah Potret Perjalanan (Jakarta: Penerbit Paramadina,1997), 3
} 
madrasah diniyah yang bersifat non formal, kini banyak pesantren yang memiliki lembaga pendidikan yang bersifat formal seperti Sekolah Dasar (SD), Madrasah Ibtidaiyah (MI), Sekolah Menengah Petama (SMP), Madrasah Tsanawiyah, (MTs), Sekolah Menengah Atas (SMA), Sekolah Menengah Kejuruan (SMK), Madrasah Aliyah (MA), bahkan banyak pesantren kini yang telah memiliki Perguruan Tinggi (PT).

Pesantren saat ini mengintegrasikan antara pendidikan pesantren dan pendidikan sekolah umum yang kemudian dikenal dengan istilah Sekolah Berbasis Pesantren (SBP). Pondok Pesantren An-Nur Bantul yang berdiri tahun 1979, salah satu pesantren yang menerapkapkan model pendidikan Sekolah Berbasiskan Pesantren (SBP). Pesantren ini memiliki sekolah dari tingkat dasar sampai perguruan tinggi. Semua siswa-siswi di lembaga pendidikan (sekolah) yang dimiliki pesantren ini adalah santri pesantren. Dalam hal ini, peneliti tertarik untuk meneliti salah satu lembaga pendidikan yang dimiliki pesantren ini, yakni Madrasah Aliyah (MA) Al-Ma'had An-Nur, berdasarkan observasi penelitian, peneliti menemukan peningkatan jumlah siswa-siswi yang signifikan dari tahunketahun terutama siswa-siswi angkatan tahun 2012/2013 sampai 2019/2020. ${ }^{4}$

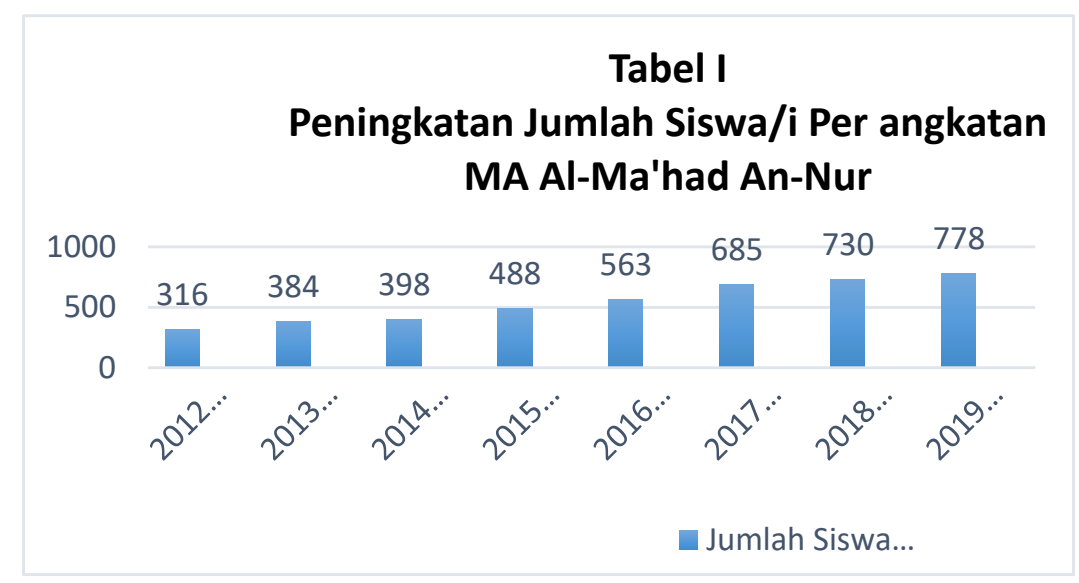

${ }^{4}$ Wawancara dengan AK pada 14 September 2019 di kantor MA Al Ma'had An-Nur Bantul. 
Peningkatan jumlah siswa-siswi MA Al-Ma'had An-Nur terus meningkat dari tahun-ketahun angkatan tahun 2012/2013 ke tahun 2013/2014, naik 21,5 \%, tahun 2013/2014 ke tahun 2014/2015 naik 3,6 \%, tahun 2014/2015 ke tahun 2015/2016 naik 22,6 \%, tahun 2015/2016 ke tahun 2016/2017 naik 15,7 \%, tahun 2017/2018 ke tahun 2018/2019 naik 21,2\%, tahun 2018/2019 ke tahun 2019/2020 naik 6,5\%. Begitu pula jumlah pendaftar dan kuota penerimaan siswasiswi terus bertambah. ${ }^{5}$

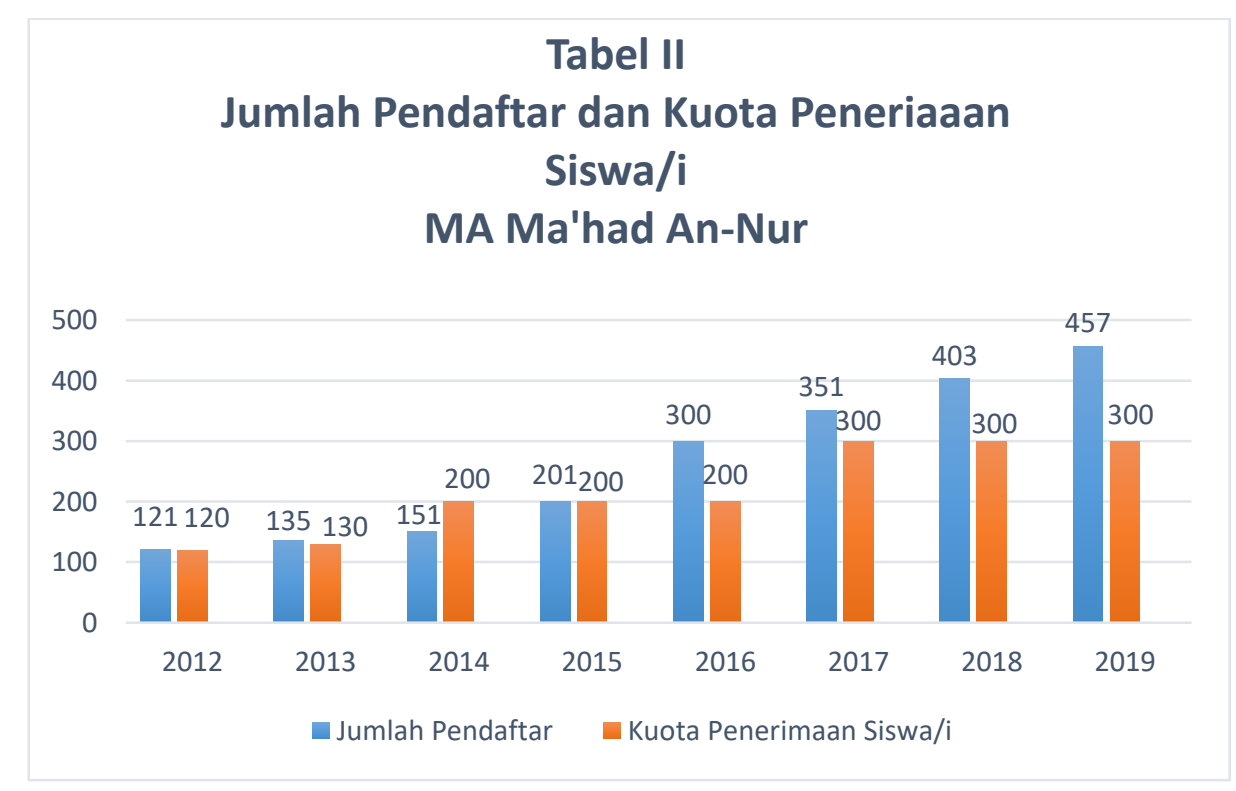

Tabel di atas, menunjukkan kenaikan jumlah pendaftar dari tahun-ketahun rata-rata diatas angka 10\%, namun pada tahun 2014, jumlah pendaftar tidak mencapai kuota penerimaan siswa-siswi MA Al-Ma'had An-Nur, hal ini menurut Abdul Kirom (staf pengajar sekaligus alumni), yang mendorong adanya diskusi internal peningkatan kualitas sekolah dan jumlah siswa. ${ }^{6}$ Adapun kaitannya dengan jumlah pendaftar yang tidak diterima di MA An-Nur, maka pihak sekolah menyarankan untuk mendaftar di tahun depan, sembari nyantri di pesantren An-

\footnotetext{
${ }^{5}$ Wawancara dengan AK pada 14 September 2019 di kantor MA Al Ma’had An-Nur Bantul.

${ }^{6}$ Wawancara dengan AK pada 14 September 2019 di kantor MA Al Ma'had An-Nur Bantul.
} 
Nur, atau direkomendasikan di sekolah setingkat yang memiliki pondok pesantren di daerah Bantul dan sekitarnya. ${ }^{7}$

Hal-hal tersebut diatas, yang mendorong peneliti untuk meneliti lebih lanjut berkaitan dengan, bagaimana MA Al-Ma'had An-Nur selaku sekolah yang setingkat dengan SMA meningkatkan jumlah pendaftar dengan tema " Strategi Pemasaran Sekolah Berbasis Pesantren ( Studi di Madrasah Aliyah Al-Ma'had AnNur Bantul )".

Adapun metode yang digunakan oleh peneliti dalam penelitian ini ialah metod penelitian kualitatif, dengan teknik wawancara, observasi, dan triangulasi. Sdangkan analisa datanya, peneliti menggunakan Miles dan Huberman.

\section{B. Metode Penelitian}

Jenis penelitian ini adalah penelitian lapangan (field research), yakni peneliti melakukan penelitian secara langsung ke lapangan. ${ }^{8}$ Metode dalam penelitian ini adalah metode observasi, wawancara, dan dokumentasi. ${ }^{9}$ Adapun sumber data yang digunakan peneliti dalam penelitian ini adalah 1). Data primer, 2). Data sukender, dan 3). Data derivative. ${ }^{10}$

\section{Hasil dan Pembahasan}

\section{Strategi Pemasaran Sekolah Berbasis Pesantren}

Strategi pemasaran ialah pemikiran pemasaran yang merupakan alat bagi unit pemasaran untuk mencapai sasaran pemasaran. Strategi ini terdiri dari strategi-strategi khusus untuk pasar sasaran, bauran pemasaran, penempatan strategi pasar dan tingkat pembiayaan pemasaran. Strategi pemasaran harus merinci segmen pasar yang akan menjadi fokus pemasaran. Segmen-segmen

\footnotetext{
${ }^{7}$ Wawancara dengan IM (Kepala MA Al-Ma'had An-Nur) pada 19 September 2019

${ }^{8}$ L.J. Moleong, Metodologi Penelitian Kualitatif, edisi Revisi (Bandung: PT Remaja Rosdakarya, 2013).

${ }^{9}$ Sugiyono, Metodologi Penelitian Pendidikan, Pendekatan Kuantitatif, Kualitatif, dan R\&D, Bandung: Alfabeta, 2019), 329

10 Andi Prastowo, Memahami Metode-Metode Penelitian (Yogyakarta: Ar-Ruzz Media, 2014).
} 
tersebut membedakan kebutuhan dan keinginan respon terhadap pemasaran kemapuanlabaan. ${ }^{11}$

Strategi pemasaran meliputi unsur utama keberhasilan pemasaran diantanya; pertama, segmentasi pasar (mengidentifikasi dan membentuk kelompok pembeli atau konsumen secara terpisah); kedua, targeting (memilih satu atau lebih segmen pasar yang akan dimasuki) ; ketiga, Positioning (penetapan posisi pasar dengan tujuan untuk membangun dan mengkomunikasikan keunggulan bersaing produk yang ada di pasar) ; keempat, elemen bauran pemasaran (Product, Price, Promotion, dan Place); dan kelima, biaya bauran pmasaran. ${ }^{12}$

Dalam menjalankan strategi pemasaran pendidikan, terdapat tiga komponen dasar yang sangat berpengaruh, yaitu: (1) integrated marketing; (2) create customer satisfaction; dan (3) a profit. ${ }^{13}$ Tiga hal tersebut, sebagai syarat utama yang perlu dipertimbangkan dalam menjalankan strategi pemasaran jasa pendidikan agar dapat menghasilkan proses pemasaran yang berkualitas dan mudah diterima oleh konsumen jasa pendidikan.

Dalam konteks pemasaran jasa pendidikan, bauran pemasaran (Marketing MIX) adalah unsur-unsur yang sangat penting dan dapat dipadukan sedemikian rupa sehingga dapat menghasilkan strategi pemasaran yang digunakan untuk memenangkan persaigan. ${ }^{14}$ Unsur-unsur yang terdapat dalam bauran pemasaran ada 7P yaitu; pertama, Product (produk) jasa apa yang ditawarkan; kedua, price (harga) strategi penentuan harga; ketiga, place (lokasi/tempat) dimana jasa diberikan; keempat, promotion (promosi) bagaimana promosi dilakukan; kelima, people (SDM) kualitas, kualifikasi, dan kompetensi yang dimiiki oleh orang yang terlibat dalam jasa pendidika; keenam physical evidence (bukti fisik) sarana prasarana; dan ketujuh, process (proses) menejeman layanan pembelajaran yang diberikan.

${ }^{11}$ Mahmud Machfoedz, Pengantar Pemasaran Modern (Yogyakarta: UUP AMP YKPN, 2005), 15.

${ }^{12}$ Fandy Tjiptono, Strategi Pemasaran (Yogyakarta: Andi,2008), 6

${ }^{13}$ Imam Machali dan Ara Hidayat, The Handbook of Education Management: Teori dan Praktik Pengeloaan Sekolah/Madrasah di Indonesia, cet. ke-1, (Jakarta: Prenadamedia Group, 2016), hal 283.

14 Imam Machali dan Ara Hidayat, The Handbook of Education ... 291 


\section{a. Bauran Pemasaran (Marketing Mix)}

1) Produk (Product)

Salah satu tugas dan tanggung jawab mereka yang berkecimpung di bidang manejemen pemasaran adalah memikirkan desain produk. ${ }^{15}$ Produk adalah segala sesuatu yang dapat ditawarkan kepada pasar untuk diperhatikan, diperoleh digunakan atau dikonsumsi sehingga dapat memenuhi kebutuhan dan keinginan konsumen.

2) Pembiayaan (Price)

Pembiayaan atau harga (Price) merupakan jumlah uang yang harus dibayarkan oleh konsumen untuk mendapatkan suatu produk. ${ }^{16}$ Harga diukur dengan nilai yang dirasakan dari produk yang ditawarkan jika tidak maka konsumen akan membeli produk lain dengan kualitas yang sama dari penjualan saingannya.

3) Lokasi (Place)

Tempat usaha atau toko merupakan lokasi di mana perusahaan bermarkas dan melakukan aktivitas kegiatannya. ${ }^{17}$ Bagi usaha konvensional aspek ini memang sangat penting, harus memperhatikan apakah lokasi tersebut cukup strategis dan mudah dikunjungi konsumen.

4) Promosi (Promotion)

Promosi merupakan suatu aktivitas yang mengkomunikasikan keunggulan produk dan berhubungan langsung dengan masyarakat. ${ }^{18}$ Promosi bertujuan untuk memberikan informasi dan meyakinkan konsumen akan manfaat produk yang dihasilkan.

5) Sumber Daya Manusia (People)

Sumber daya manusia dalam kontek pendidikan adalah orang-orang yang terlibat dalam proses penyampaian jasa pendidikan, separti Tata Usaha (TU), kepala sekolah, guru dan karyawan (pendidik dan tenaga

\footnotetext{
15 Panji Anogara, Manajemen Bisnis (Jakarta : Rineka Cipta,1997), 220

${ }^{16}$ Imam Machali dan Ara Hidayat, The Handbook of Education ... 292

${ }^{17}$ Imam Machali dan Ara Hidayat, The Handbook of Education ... 293

18 Imam Machali dan Ara Hidayat, The Handbook of Education ... 293
} 
kependidikan). ${ }^{19}$ Sumber daya pendidikan dan tenaga kependidikan ini sangat penting bagi keberlangsungan penyelenggaraan jasa pendidikan.

6) Bukti fisik (Physical Evidence)

Physical Evidence atau bukti fisik adalah lingkungan tempat jasa disampaikan dan tempat penyedia jasa dengan konsumen berinteraksi. ${ }^{20}$ Beserta dengan semua komponen lainnya yang mendukung terwujudnya atau terkomunikasinya jasa.

7) Proses (Procees)

Dalam kontek jasa pendidikan, proses adalah proses pendidikan yang segala kegiatan yang mendukung terselenggaranya proses kegiatan belajar mengajar guna terbentuknya produk/lulusan yang diingginkan. ${ }^{21}$ Proses jasa pendidikan merupakan satuan kegiatan yang dimulai dari pemasaran, penerimaan peserta didik baru, seleksi, pengelompoan kelas (jurusan/peminatan), proses pembinaan sampai kelulusan peserta didik.

Menurut peneliti, hadirnya unsur-unsur bauran pemasaran dalam strategi pemasaran jasa pendidikan belum mencukupi, apabila pengelolan sumber daya manusia yang dimiliki organisasi tidak terkelola dengan baik. Dalam pengelolaan sumber daya manusia didalam organisasi dibutuhkan perencanaan, pengorganisasian, pelaksanaan dan pengawasan guna mencapai tujuan yang diharapkan.

\section{b. Sekolah Berbasis Pesantren}

Pondok pesantren adalah lembaga pendidikan keagamaan Islam yang menurut sebagian ahli merupakan produk asli Indonesia. ${ }^{22}$ Pesantren sebagai lembaga pendidikan memiliki kekhasan tersendiri. Kekhasan tersebut ada pada lima komponen dasar yang melekat pada diri pesantren, yakni kyai, santri, masjid, pondok dan kitab kuning (kitab klasik). ${ }^{23}$ Pesantren merupakan lembaga pendidikan Islam tertua di Indonesia, walaupun kajian-kajian tentang

\footnotetext{
${ }^{19}$ Imam Machali dan Ara Hidayat, The Handbook of Education ... 293

20 Imam Machali dan Ara Hidayat, The Handbook of Education ... 293

${ }^{21}$ Imam Machali dan Ara Hidayat, The Handbook of Education ... 294

${ }^{22}$ Azra, Azumardi. Pendidikan Islam ; Tradisi dan Modernisasi Menuju Milenium Baru. ( Jakarta : Logos Wacana Ilmu, 1999), 105.

${ }^{23}$ Samsul Nizar, Sejarah Sosial dan Dinamika Intelektual (Jakarta: Kencana Prenada Media Grup, 2013), 140.
} 
kapan dan dimana pesantren pertama kali didirikan para sejarawan berbeda pendapat. Namun menurut Halim Soebahar, pesantren berdiri pertama kali oleh Maulana Ibrahim pada tahun 1399 Masehi. $^{24}$

Pesantren yang semula hanya mendirikan madrasah diniyah yang mengajarkan ilmu agama Islam dan bersifat non formal, tapi kini, dibanyak pesantren telah mendirikan sekolah/madrasah yang bersifat formal, mulai tingkat dasar (SD/MI) sampai Perguruan Tinggi (PT). Hal tersebut, dilakukan bukan dalam rangka pesantren inggin meninggalkan ilmu-ilmu agama Islam yang menjadi kekhasan pesantren, tapi dalam menjawab tantangan zaman.

Sekolah Berbasis Pesantren (SBP) merupakan model pendidikan yang mengintegrasikan keunggulan sistem pendidikan yang diselenggarakan di sekolah dan keunggulan sistem pendidikan di pesantren, melalui pengembangan tiga dimensi pendidikan unggul. Pemilikan landasan moralitas keagamaan yang kuat, penguasaan ilmu pengetahuan dan teknologi, serta memiliki dan menguasai bentuk-bentuk keterampilan-keterampilan bekerja yang akan menunjang kehidupannya setelah selesai mengikuti pendidikan. ${ }^{25}$

Adapaun pengertian lain dari Sekolah Berbasis Pesantren (SBP) adalah model pendidikan yang mengintegrasikan kurikulum departemen pendidikan/departemen agama dengan kurikulum kepesantenan yang diharapkan dapat menciptakan lulusan yang ilmuan dan agamawan. Pada tataran implementasinya, singkatnya siswa-siswi yang bersekolah di sekolah yang menerapkan sistem SBP adalah siswa-siswi sekaligus santri pada lembaga pendidikan yang menerapkan sistem tersebut. Dalam hal ini, yang dimaksud dengan SBP adalah salah satu sekolah yang dimiliki pondok pesantren An-Nur Bantul, sekolah tersebut bernama Madrasah Aliyah (MA) Al-Ma'had An-Nur.

${ }^{24}$ Abd Halim Soebahar, Modernisasi Pesantren; Studi Tranformasi Kepemimpinan Kiai dan Sistem Pendidikan Pesantren (Yogyakarta: Lkis, 2013), 33

${ }^{25}$ Kementerian Pendidikan dan Kebudayaan RI, Direktorat Jenderal Pendidikan Dasar dan Menengah, Direktorat Pembinaan SMP, Laporan Monitoring dan Evaluasi Program Sekolah Berbasis Pesantren(Jakarta: Kemendikdasmen, 2016), 14 


\section{Strategi Pemasaran Sekolah Berbasis Pesantren di Madrasah Aliayah Al-}

\section{Ma'had An-Nur}

Setelah peneliti melakukan penelitian berkaitan dengan strategi pemasaran sekolah berbasis pesantren di Madrasah Aliyah Al-Ma'had An-Nur, maka peneliti menemukan adanya unsur bauran pemasaran (marketing mix) dalam pemasaran jasa pendidikann yang dilakukan di MA Al-Ma'had An-Nur, agar lebih jelas, peneliti akan memaparkannya dalam pembahasan dibawah ini.

\section{a. Strategi Produk (Produck) Jasa Pendidikan di MA Al-Ma'had An-Nur}

Produk dalam kontek jasa pendidikan adalah jasa yang ditawarkan kepada pelanggan berupa reputasi, prospek, dan variasi pilihan. Dalam hal ini MA AlMa'had An-Nur menawarkan produk jasa pendidikan berupa sekolah yang terintegrasi antara kurikulum sekolah formal (kurikulum2013) dan kepesantrenan. Sebagaimana kutipan wawancara berikut;

.....Di sekolah ini, sekolah sambil mondok. Siswa ya, santri pesantren juga. Artinya sekolah ini menggabungkan kurikulum sekolah formal dan pesantren. ${ }^{26}$......

Terintegrasinya kurikulum sekolah formal dengan kepesantrenan bagian dari pengejawantahan misi MA Al-Ma'had An-Nur poin dua yang berbunyi "membangun pribadi santri dalam ilmu pengetahuan Agama sekaligus ilmu pengetabuan umum'.

\section{b. Strategi Pembiayaan (Price) Jasa Pendidikan MA Al-Ma'had An-Nur}

bahwasanya MA Al-Ma'had An-Nur dalam menentukan pembiayaan jasa pendidikan yang dimiliki (sekolah dan pesantren) tidak berorientasi keuntungan atau memperhatikan pembiayaan yang ditetapkan oleh kompetitornya (lembaga pendidikan yang sama dengan MA-Al-Ma'had AnNur). Namun lebih mempertimbangkan kepada kemampuan rata-rata konsumen/pelanggan jasa pendidikan (wali murid). Hal ini menurut peneliti, MA Al-Ma'had An-Nur mencitrakan diri sebagai lembaga pendidikan dengan biaya yang terjangkau. pembiayaan perbulan di MA Al-Ma'had An-Nur sebesar Rp 390.000.0027, meliputi sebagai berikut;

26 Wawancara dengan IZ (kepala madrasah) pada 22 Desember 2019 di kantor kepala madrasah MA Al-Ma'had An-Nur

27 Arsip MA Al-Ma'had An-Nur 2019 
Tabel 8 Biaya Per Bulan Pendidikan di MA Al-Ma'had An-Nur

\begin{tabular}{|l|l|l|}
\hline No & \multicolumn{1}{|c|}{ Keperluan } & \multicolumn{1}{|c|}{ Jumlah } \\
\hline 1 & Sekolah & $\mathrm{Rp} 120.000 .00$ \\
\hline 2 & Makan & $\mathrm{Rp} 185.000 .00$ \\
\hline 3 & Minum & $\mathrm{Rp} 15.000 .00$ \\
\hline 4 & Sahriyah (Asrama) & $\mathrm{Rp} \mathrm{35.000.00}$ \\
\hline 5 & Pengembangan yayasan & $\mathrm{Rp} \mathrm{5000.00}$ \\
\hline 6 & Unit kesehatan santri & $\mathrm{Rp} \mathrm{5000.00}$ \\
\hline 7 & Madrasah Diniyah & $\mathrm{Rp} 15.000 .00$ \\
\hline 8 & Pembangunan Jumlah & $\mathrm{Rp} \mathrm{10.000.00}$ \\
\hline & & $\mathrm{Rp} \mathrm{390.000.00,}$ \\
\hline
\end{tabular}

Adapun rincian daftar ulang bagi siswa-siswi yang lulus seleksi masuk MA Al-Ma’had An-Nur 2019/2020 . ${ }^{28}$ sebagai berikut;

Tabel 9 Biaya Daftar Ulang Siswa-siswi MA Al-Ma'had An-Nur Tahun 2019/2020

\begin{tabular}{|c|c|c|}
\hline No & Keperluan & Jumlah \\
\hline 1. & Administrasi Pondok & Rp 60.0000 .00 \\
\hline 2 & Administrasi Madrasah Diniyah & Rp 175.000 .00 \\
\hline 3. & Syahriah Pondok \& Kost Makan Juli-Juni 2019 & Rp 405.000.00 \\
\hline 4. & Buku Izin, Buku Panduan Wali Santri \& KTS & Rp 30.000 .00 \\
\hline 5. & Kitab Kepesantrenan (5 Kitab) & Rp 165.000 .00 \\
\hline 6. & Pusat Kesehatan Pesantren (Puskestren) & $\operatorname{Rp} 30.000 .00$ \\
\hline 7 & Forum Ta'aruf Santri (FORTASI) & Rp 150.000 .00 \\
\hline 8 & Kotak Almari Santri & Rp 200.000.00 \\
\hline 9 & Pelalatan Kamar dan Makan & Rp 60.000 .00 \\
\hline 10 & Perlengkapan Tidur & Rp 150.000 .00 \\
\hline 11 & Kalender 3 Eksemplar & Rp 50.000.00 \\
\hline
\end{tabular}

28 Arsip MA Al-Ma’had An-Nur 2019 


\begin{tabular}{|l|l|l|}
\hline 12 & 2 Baju Almamater & Rp 140.000 .00 \\
\hline 13 & Buku Tulis An-Nur (3 Lusin) & Rp 90.000.00 \\
\hline 14 & Jariyah Pembangunan Pondok (Minimal) & Rp 1000.000 .00 \\
\hline 15 & Biaya Pengadaan dan Kegiatan Bulanan & Rp 195.000 .00 \\
\hline \multicolumn{2}{|c|}{ Jumlah } & Rp 2.900.000.00 \\
\hline
\end{tabular}

Biaya Daftar Ulang Siswa-siswi MA Al-Ma'had An Nur adalah biaya Pendaftaran Pondok Pesantren An Nur dikarenakan siswa siswi MA AlMa'had An Nur wajib mondok (tinggal) di Pondok Pesantren An Nur.

\section{c. Strategi Tempat (Place) Jasa Pendidikan MA Al-Ma'had An-Nur}

Place dalam hal ini, adalah dimana lokasi terselenggaranya jasa pendidikan atau lokasi sekolah mempunyai peranan yang sangat penting, karena lingkungan dimana jasa pendidikan disampaikan merupakan bagian dari nilai dan manfaat jasa yang dipersepsikan cukup berperan dalam menentukan pilihan. MA Al-Ma'had An-Nur beralamatkan di kampung Ngrukem, Desa Pendowoharjo, Kecamatan Sewon, Kabupaten Bantul, Daerah Istimewa Yogyakarta, jarak sekolah ini dari pusat kota Yogyakarta sekitar 8 kilometer, sedangkan dari pusat kota Bantul sekitar 1 kilometer.

\section{d. Strategi Promosi (Promotion) Jasa Pendidikan MA Al-Ma'had An-Nur}

Promotion (promosi) merupakan suatu bentuk komunikasi pemasaran yaitu aktifitas pemasaran yang berusahan menyebarkan informasi, mempengaruhi atau mengingatkan pasar sasaran atas lembaga dan produknya agar bersedia menerima, membeli bahkan loyal pada produk yang ditawarkan oleh lembaga tersebut. Lembaga pendidikan dalam prespektif menajemen adalah sebuah organsisasi yang menyediakan keilmuan atau melakukan suatu usaha dalam bidang keilmuan. MA Al-Ma'had An-Nur dalam mempromosikan lembaganya dengan cara seperti kutipan wawancara ${ }^{29}$ berikut:

"Dari mulai berdiri sampe sekarang kami tidak pernah melakukan promosi seperti pasang iklan dikoran atau TV. Kami ada papan

${ }^{29}$ Wawancara dengan MH (Ketua Panitia PPDB) pada 27 Desember 2019 di ruang guru MA Al-Ma'had An-Nur. 
iklan di jalan Bantul, itu saja tidak mbayar, buat wangun-wangun (formalitas) tetenger (penanda) disini ada sekolah dan pondok. Yang kami lakukan hanya memanfaatkan teknologi, seperti wabset, youtube, media sosial yang dikelolah pondok pesantren sebagai media promosi dan komunikasi”

\section{e. Strategi Bukti Fisik (Physical Evidence) Jasa Pendidikan MA Al- Ma'had An-Nur}

Physical evidence, merupakan saranan dan prasarana yang dimiliki sekolah dalam menunjang aktifitas jasa pendidikan untuk menunaikan janji-janji kepada pelanggannya. Sarana fisik ini merupakan suatu hal yang secara nyata mempengarui keputusan wali murid (pelanggan jasa pendidikan) untuk menitipkan putra/inya ke suatu sekolah. prasarana-prasarana yang dimiliki MA Al-Ma'had An-Nur ${ }^{30}$ sebagaimana kutipan wawancara berikut;

"Jadi gini mas, sekolah yang dimiliki pondok pesantren itu batine akeh (untungnya banyak), contonya kami ini, semua prasarana-prasarana yang dimiliki pondok pesantren adalah fasilitas sekolah juga'

\section{f. Strategi Proses (Process) Jasa Pendidikan di MA Al-Ma'had An-Nur}

Proses jasa pendidikan merupakan satuan kegiatan yang dimulai dari pemasaran, penerimaan peserta didik baru, seleksi, pengelompoan kelas (jurusan/peminatan), proses pembinaan sampai kelulusan peserta didik.

\section{Pelaksanaan Pemasaran Jasa Pendidikan di MA Al-Ma'had An-Nur}

\section{a. Perencanaan Pemasaran Jasa Pendidikan MA Al Ma'had An-Nur}

Perencanaan merupakan langkah pertama yang harus dilaksanakan seorang manajer, fungsi perencanaan dalam pemasaran jasa pendidikan bertujuan untuk mengurangi atau mengimbangi ketidakpastian dan perubahan yanga akan datang, memusatkan perhatian kepada sasaran, tercapainya tujuan secara efisien dan efektif. Menurut Abdul Kirom, MA Al-Ma'had An-Nur tahun 2014, mulai menata organisasi sekolah dan kerjasama antar lembaga

30 Wawancara dengan. IM pada 28 desember 2019 di ruang guru MA Al-Ma'had An-Nur 
pendidikan yang ada di pondok pesantren An-Nur. ${ }^{31}$ Kutipannya sebagai berikut;

"2014 tahun berarti bagi sekolah, target kami 200 siswa, yang daftrar cuma 151. Setelah itu, kami mulai menata organisasi sekolah dan mulai kerjasama dengan pondok sama diniyah. Tak ajak ngobrol semua alumni yang bisa tak bubungi ben mikerke (supaya memikirkan) sekolah, guru-guru tak opyak-opyak (seruan untuk bekerja keras) supaya tidak terjadi lagi. Setelah itu baru ada diskusi-diskusi tentang peningkatkan kualias dan jumlah siswa. Alhamdulilah 2015, target tercapai

MA Al-Ma’had An-Nur dalam pemetaan untuk minangkatkan jumlah pelanggan jasa pendidikannya. mengembangkan konsep segmentasi, targeting dan positioning. Hal tersebut dilakukan semenjak tahun 2014, dan terbukti berhasil. Adapun uraniannya sebagai berikut;

1) Segmentasi Pasar

Segmentasi pasar, yaitu tindakan mengindentifikasi dan membentuk kelompok pembeli atau konsumen. Pada tahapan ini lembaga pendidikan akan mengklasifikasi kelompok pelanggan berdastkan ciri khas dan karakternya masing-masing. Dalam hal ini MA Al-Ma'had An-Nur mengelompokan pelanggan jasa pendidikannya berdasrkan organisasi kemasyarakatan Islam, kutipannya ${ }^{32}$ sebagai berikut;

"seinggat saya waktu itu kami rapat. Klo nggak salah 10 orang, kami mikirmikir siapa yang bakal masuk kesini tabun depan. Kami identifikasi berdasarkan organisasi, NU, Mubamadiyah, Persis apa HTI"

MA Al-Ma'had An-Nur dalam hal ini, mengelompokan pelanggan pendidikannya berdasarkan hanya sebatas organisasi Islam dan menafikan variabel-variabel yang lain seperti demografi, sosio-ekonomi, psikologi, geografi, maupun behavior atau prilaku konsumen. Menurut hemat peneliti hal ini tidak berlebihan, karena jasa pendidikan yang ditawarkan MA AnNur pada aspek demografi, psikologi, geografi, dan behavior tidak memiliki masalah.

2) Targeting (menetapkan target)

\section{Nur}

31 Wawancara dengan AK pada tanggal 28 Desember 2019 di ruang guru MA Al-Ma’had An-

32 Wawancara dengan AK pada tanggal 28 Desember 2019 di ruang guru MA Al-Ma’had An- 
Tergeting merupakan tindakan menilai ketertarikan dan minat dari beragam segmen pasar, kemudian mentukan segmen pasar mana yang akan dijadikan sebagai segmen pasar. Dalam pemasaran jasa pendidikan hal ini targeting menjadi komponen kedua setelah segmenting, setelah penyedia jasa pendidikan melakukan pengelompokan pasar dengan karekternya masing-masing, kemudian menentukan segmen pasar mana yang akan dijadikan konsumen jasa pendidikan. Target yang menjadi fokus pelayanan jasa pendidikan MA An-Nur adalah anggota organisasi Islam Nahdlatul Ulama (Nabdiyin), kutipan wawancaranya ${ }^{33}$ sebagai berikut;

Orang NU yang kami target mas. Alasanya muasis (pendiri) pondok NU tulen, semua guru-guru disini NU semua. Tapi kami tidak menutup yang lain buat sekolah disini, Mubamadiyah boleh, PKS boleh, babkan ada santri sini yang bapaknya dedengkot (pemimpin) HTI"

Kaum Nabdiyin (sebutan buat anggota organisasi NU), dipilih sebagai target utama konsumen jasa pendidikan yang ditawarkan MA Al-Ma'had An-Nur. Menurut peneliti target tersebut tepat, mengingat pendiri pondok pesantren An-Nur selaku induk sekolah ini adalah anggota NU, hal tersebut terbukti, ditahun-tahun selanjutnya pendaftar di MA Al-Ma'had An-Nur meningkat dari tahun-ketahun.

3) Positioning

Positioning atau penempatan produk yang merupakan upaya untuk menempatkan posisi produk dalam menghadapi persaingan. Pengembangan strategi pemasaran ini bertujuan untuk mempengaruhi tentang bagaimana suatu segmen pasar tertentu menilai produk maupun jasa ketika dibandingkan dalam kompetisi pasar. Dalam dunia pendidikan, keberadaan positioning sangat membantu pihak sekolah untuk menyakinkan konsemen jasa pendidikan bahwa jasa pendidikan yang dihasilkan berbeda, layak dan berkualitas. Dalam hal ini MA Al-Ma'had An-Nur tampil sebagai sekolah yang mengingrasikan kurikulum sekolah umum dan kurikulum kepesntrenan. Sebagimana penuturan Abdul Kirom, sekolah kami integrasi

33 Wawancara dengan AK pada tanggal 28 Desember 2019 di ruang guru MA Al-Ma'had AnNur 
antara sekolah dan pesantern. Sekolah ini mempunyai jurusan sekolah umum dan jurusan kepesantrenan. ${ }^{34}$

\section{b. Pengorganisiran Pemasaran Jasa Pendidikan MA Al-Ma'had An-Nur}

Pengorganisasian adalah upaya mengatur sumber daya manusia yang dimiliki suatu organisasi demi tercapainya visi dan misi sebuah organisasi. Untuk mencapai visi dan misi tersebut diperlukan pemimpin sekaligus manejer yang dapat memaksimalkan sumber daya manusia yang dimiliki oleh sebuah organisasi. Fungsi pengorganisasian mengelompokkan semua orang, alat, tugas dan wewenang yang ada dijadikan satu kesatuan yang kemudian digerakkan melaksanakan apa yang sudah direncanakan. Pengorganisasian memudahkan pemimpin disebuah organisasi untuk mengawasi dan menentukan orang-orang yang dibutuhkan dalam menjalanjan tugas-tugas yang telah diberikan

Dalam hal ini, Kepala madrasah MA Al Ma'had AN-Nur membentuk Panitia Penerimaan Peserta Didik Baru (P3DB), kepanitiaan ini bekerja sejak 19 Januari 2019, sampai dengan 30 Mei 2019. Kepanitiaannya sebagai berikut;

$\begin{array}{ll}\text { Penaggung Jawab } & \text { : Kepala Madrasah } \\ \text { Pengarah } & \text { : Drs. Subakir, M.S.i } \\ & \text { Drs. H. Nasihun. } \\ \text { Ketua } & \text { : Mahrus. S.Pd.i } \\ \text { Sekretaris } & \text { : Dwi I'sfa } \\ \text { Bendahara } & : \text { Alfi Sustriyani. S.Pd. } \\ \text { Sie Yudisium } & : \text { Abdul Kirom. M,Hum. } \\ & \text { Nurocman. M.S.I } \\ \text { Sie Perlengkapan } & : \text { Drs. Mustofa } \\ \text { Sie Pendaftaran } & : \text { Ary Suprihatin. }{ }^{35}\end{array}$

Panitia Penerimaan Peserta Didik Baru (P3DB) yang dibentuk kepala MA Al-Ma'had An-Nur. Berdasarkan hasil observasi, peneliti menemukan, bahwa guru-guru yang menjadi panitia penerimaan peserta didik tahun ajaran

\section{Nur}

${ }^{34}$ Wawancara dengan AK pada tanggal 28 desember 2019 di ruang guru MA Al-Ma’had An-

35 Surat keputusan kepala madrasah MA Al-Ma'had An-Nur tentang pembentukan Panitia Penerimaan Peserta Didik Baru, 2019P 
2019/2020, hanya bersifat kordinator, karena pada saat pelaksanaan semua kegiatan seksi-seksi yang ada menunjuk beberapa guru untuk bekerja dalam kegiatan tersebut.

\section{c. Pelaksanaan Pemasaran Jasa Pendidikan}

Actuanting adalah tindakan didalam sebuah organisasi yang mengupayakan agar anggota organisasi siap bekerja dengan senang hati sesuai dengan tugas dan wewenang dalam rangka mencapai tujuan yang dikehendaki secara efektif. Fungsi pengarahan adalah upaya untuk menciptakan suasana dinamis, sehat agar kinerjanya lebih efektif dan efisien. Hal yang diperlukan untuk melaksanakan fungsi penggerak adalah kepemimpinan. Seorang pemimpin harus mampu memotivasi dan membimbing bawahannya.

Beberapa tugas kegiatan pada fungsi pengarahan diantaranya; pertama, memberi tugas dan wewenang serta menjelaskan secara rutin tentang pekerjaan; kedua; membimbing dan memberikan motifasi kepada pekerja agar supaya bisa bekerja secara efektif dan efisien; ketiga, menjelaskan semua kebijakan yang telah ditetapkan.

Dalam hal ini, kepala MA Al-Ma'had An-Nur setelah membentuk kepanitiaan penerimaan peserta didik baru, baru memberikan tugas dan wewenang panitia tersebut, tugas dan wewenangnya sebagaimana dibawah ini.

1) Ketua
a) Menyusun pembagian tugas panitia penerima peserta didik
b) Menyusun rencana kerja panitia penerima peserta didik
c) Mengkoordinir pelaksanaan panitia penerimaan peserta didik baru
d) Mengawasi pelaksanaan panitia penerimaan peserta didik baru
e) Memberikan masukan dan evaluasi terhadap pelaksanan panitia penerimaan peserta didik baru

2) Sekretaris

a) Merancang format penerimaan panitia penerimaan peserta didik baru dari pendaftaran sampai dengan daftar ulang

b) Bertanggung jawab atas berkas surat menyurat dan administrasi panitia penerimaan peserta didik baru 
c) Mendokumentasikan arsip/berkas-berkas panitia penerimaan peserta didik baru

d) Menyiapkan berkas untuk pelaksanaan seleksi

e) Membuat jadwal dan daftar pengawas seleksi

f) Membuat jadwal dan petugas koreksi hasil seleksi

g) Mendokumentasi hasil seleksi

h) Membuat laporan pelaksanaan panitia penerimaan peserta didik baru

i) Membuat perangkat sosialisasi panitia penerimaan peserta didik baru

3) Bendahara

a) Membuat rancangan anggaran panitia penerimaan peserta didik baru

b) Membuat aliran pemasukan dan pengeluaran panitia penerimaan peserta didik baru secara cermat

c) Mengelola dana panitia penerimaan peserta didik baru secara tepat dan terperinci

d) Membuat laporan penggunaan dana panitia penerimaan peserta didik baru

4) Seksi Pendaftaran

a) Menyusun jadwal pelaksanaan pendaftaran

b) Menyiapkan perangkat pendaftaran

c) Membagi petugas pelaksana pendaftaran

d) Membuat laporan pelaksanaan pendaftaran panitia penerimaan peserta didik baru

5) Seksi Yudisium

a) Membuat soal seleksi penerimaan peserta didik baru

b) Mengoreksi soal seleksi penerimaan peserta didik baru

c) Membagi tugas kepada guru-guru yang pada saat seleksi tes tulis dan lisan

d) Memberi rekomendasi peminatan sekolah dan marhalah kepesantrena kepada kepala Madrasah.

6) Seksi Perlengkapan

a) Menyiapkan ruang untuk pelaksanaan pendaftaran 
b) Menyiapkan ruang untuk pelaksanaan tes tertulis panitia penerimaan peserta didik baru

c) Menyiapkan ruang untuk pelaksanaan daftar ulang

d) Membuat denah dan petunjuk ruangan pelaksanaan panitia penerimaan peserta didik baru mulai dari pendaftaran, tes dan daftar ulang. ${ }^{36}$

\section{d. Evaluasi}

Evaluasi adalah langkah terakhir setelah perencanaan, pengorganisiran dan pengarahan. Fungsi evaluasi diantaranya; pertama, mengevaluasi keberhasilan dan target dengan cara mengikuti standar indikator yang telah ditetapkan, yaitu tugas dan wewenang kepanitiaan; kedua, melakukan klarifikasi dan koreksi terhadap penyimpangan yang ditemukan; ketiga, memberikan alternatif solusi yang mungkin bisa mengatasi maslah yang terjadi.

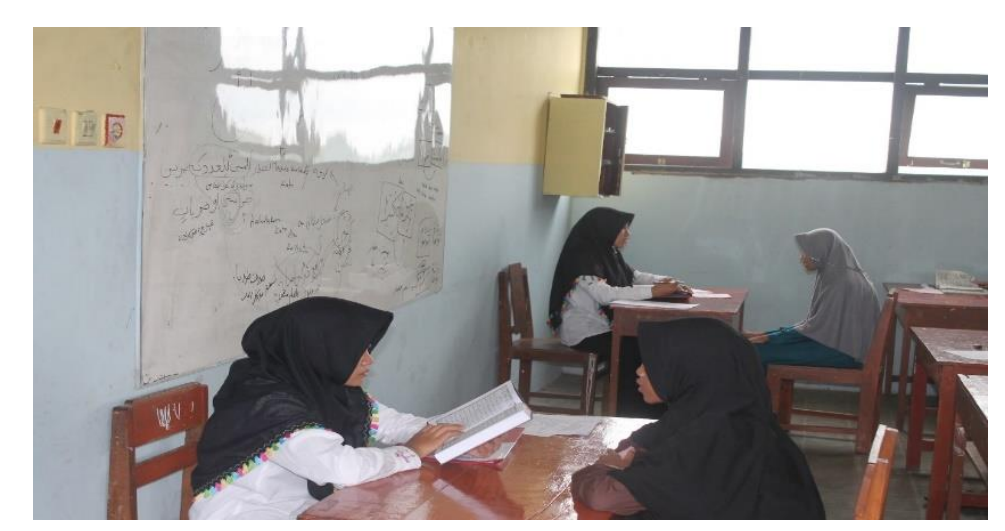

Gambar 14 Seleksi Test Lisan Calon Peserta Didik ${ }^{37}$

Dalam hal ini, pelaksanaan kerja yang dilakukan Panitia penerimaan peserta didik baru tahun 2019, menurut bapak izzat, berjalan sukses dan melampaui target yang diharapkan sekolah, kekuraannya hanya bersifat

36 Arsip MA Al-Ma'had An-Nur 2019

37 Arsip MA Al-Ma’had An-Nur 2019 
teknis. ${ }^{38}$ Hal tersebut dapat dibuktikan dari bertambahnya jumlah pendaftar yang mana tahun 2018, berjumlah 403, pendaftar di tahun 2019, naik menjadi 557 pendaftar.

\section{Faktor Pendukung, Penghambat serta Solusi dalam Pemasaran Jasa Pendidikan di MA Al-Ma'had An-Nur}

Berdasarkan pembahasan di atas tentang strategi pemasaran sekolah berbasis pesantren di MA Al-Ma'had An-Nur. Selanjutnya peneliti akan dipaparkan faktor yang menjadi pendukung dan faktor yang menjadi penghambat serta solusi yang peneliti tawarkan sebagai berikut:

\section{a. Faktor Pendukung Jasa Pendidikan MA Al-Ma'had An-Nur}

1) Sekolah yang memilki kekhasan karena mengerintegrasikan antara kurikulum sekolah formal (kurikulum 2013) dan kurikulum kepesantrenan. dan interkoneksi antara kurikulum sekolah (kurikulum 2013) dan kurikulum kepesantrenan. Implementasi sistem ini pada peserta didik, Siswa-siswi yang bersekolah di MA Aliyah Al-Ma'had An-Nur harus menjadi santri pondok pesantren An-Nur (siswa-siswi sekaligus santri/wati). Adapun implentasi sistem integrasi dalam kurikulum. Peserta didik yang bersekolah wajib mengambil salah satu peminatan pada sekolah formal antar IIK, IIS dan MIA dan pada kurikulum kepesantrenan wajib mengambil marbalah tabfiz. atau marbalah kitab. Adapun penanggung jawab kurikulum sekolah pihak MA Al-Ma'had An-Nur, sedangkan kurikulum kepesantrenan pihak MADIN Al-Furqon, kedua lembaga pendidikan tersebut terintegrasi satu sama lain.

2) Biaya pendidikan yang terjangkau. MA Al-Ma'had An-Nur menerapkan pembiayaan pendidikan yang terjangkau, biaya pendidikan perbulan di sekolah ini, hanya sebesar Rp 390.000.00, rinciannya sebagai berikut;

\begin{tabular}{|l|l|c|}
\hline No & \multicolumn{1}{|c|}{ Keperluan } & Jumlah \\
\hline 1 & Sekolah & Rp 120.000 .00 \\
\hline
\end{tabular}

38 Wawancara dengan IM pada tanggal 05 Desember 2020 di ruang guru MA Al-Ma'had An- 


\begin{tabular}{|l|l|l|}
\hline 2 & Makan & Rp 185.000 .00 \\
\hline 3 & Minum & Rp 15.000 .00 \\
\hline 4 & Sahriyah (Asrama) & Rp 35.000.00 \\
\hline 5 & Pengembangan yayasan & Rp 5000.00 \\
\hline 6 & Unit kesehatan santri & Rp 5000.00 \\
\hline 7 & Madrasah Diniyah & Rp 15.000 .00 \\
\hline 8 & Pembangunan & Rp 10.000 .00 \\
\hline Jumlah & Rp 390.000.00, \\
\hline
\end{tabular}

3) Lokasi sekolah yang mudah dijangkau dengan kendaraan pribadi dan umum. MA Al-Ma'had An-Nur beralamatkan di kampung Ngrukem, Desa Pendowoharjo, Kecamatan Sewon, Kabupaten Bantul, Daerah Istimewa Yogyakarta. Jarak sekolah ini dari pusat kota Yogyakarta sekitar 8 kilometer, sedangkan dari pusat kota Bantul sekitar 1 kilometer.

4) Memiliki media sendiri dalam mempromosikan dan merawat pelanggan jasa pendidikan yang dimiliki. MA Al-Ma'had An-Nur adalah salah satu lembaga pendidikan yang dimiliki pondok pesantren An-Nur, secara otomatis semua fasilitas yang dimiiki pondok pesantren adalah milik sekolah ini, begitupun media yang dimiliki pesantren, seperti fanspage, Insagram, chanel Youtube dan aplikasi android, dapat dimaksimalkan untuk mempromosikan kegiatankegiatan yang diselenggaran MA Al-Ma'had An-Nur sebagai media sosialisasi. Selain itu, dalam hal komunikasi dengan pelanggan jasa pendidikan yang dimiliki, MA Al-Ma'had An-Nur dapat langsung berkomunikasi dengan pelanggan jasa pendidikannya dengan cara memanfaatkan grup WhatsApp yang dimiliki oleh setiap asrama pondok pesantren An-Nur.

5) Memiliki mayoritas guru yang mumpuni dibidangnya masing-masing baik di MA Al-Ma'had An-Nur dan MADIN Al-Furqon. Guru-guru adalah lulusan pondok pesantren yang ulusan strata satu dan beberapa lulusan strata dua dari berbagai perguruan tinggi. 
6) Memiliki sarana-prasarana yang memadai. Selain itu, MA Al-Ma'had AnNur dapat memanfaatkan prasarana yang dimiliki pondok pesantren AnNur sebagai induk dari sekolah ini.

7) Menawarkan tiga proses pembinaan bagi peserta didik; pertama; proses pembinaan di asrama pondok pesantren yang diawasi oleh pengurus asrama pondok pesantren; kedua, proses pembinaan di MA Al-Ma'had An-Nur yang diawasi langsung oleh guru di sekolah; dan ketiga, proses pembinaan di Madrasah Diniyah yang diawasi oleh Ustaz/ah yang berada di MADIN. Hal ini dilakukan dalam rangka mengawal visi, misi dan target MA AlMa'had An-Nur.

\section{b. Faktor Penghambat Jasa Pendidikan MA Al-Ma'had An-Nur}

a) Integrasi kurikulum sekolah dan kurikulum pesantren belum berjalan sepenuhnya, terutama marhalah kitab, hal ini karen pihak MA Aliyah An-Nur dan pihak MADIN Al-Furqon belum mampu menstandarkan kemampun siswa-siswi (santri/wati).

b) Guru yang memiliki profesi ganda di lembaga pendidikan yang dimiliki pondok pesantern An-Nur. Dari pengamatan peneliti, peneliti menemukan beberapa guru yang memiliki profesi ganda, selain menjadi guru di MA AlMa'had An-Nur, guru tersebut juga menjadi guru di Madin Al-Furqon. Adapula guru di MADIN, yang masih berstatus mahasiswa.

\section{c. Solusi Faktor Penghambat Jasa Pendidikan MA Al-Ma'had An-Nur}

a) Menyediakan kelas persiapan Aliyah, penyediaan kelas ini untuk peserta didik yang lolos seleksi masuk MA Al-Ma'had An-Nur namun belum mampu mengikuti mata pelajaran di MADIN Al-Furqon. Hal ini, penting dilakukan agar MA Al-Ma'had An-Nur dan MADIN Al-Furqon dapat menjalankan integrasi kurikulum sekolah formal dan kurikulum kepesantrenan secara total.

b) Guru yang memiliki profesi ganda di lembaga pendidikan yang dimiliki pondok pesantren An-Nur, menurut peneliti dapat menjadi faktor pendukung dan penghambat tergantung dari guru tersebut. Menjadi faktor pendukung karena guru tersebut dapat mengawasi secara langsung peserta didik baik di sekolah maupun di MADIN, adapun faktor penghambat 
adalah, apabila guru tersebut tidak dapat fokus dan mempunyai kecendrungan diantara salah satu lembaga baik MA Al-Ma'had An-Nur ataupun MADIN Al-Furqon.

\section{Kesimpulan}

Berdasarkan hasil analisis pelaksanaan strategi pemasaran sekolah berbasis pesantren studi di MA Al-Ma'had An-Nur Bantul, maka dapat diperoleh kesimpulan sebagai jawaban atas rumusan masalah yang ada. Kesimpulan yang dimaksud adalah sebagai berikut:

1. Strategi pemasaran jasa pendidikan di MA Al-Ma'had An-Nur Bantul sebagai sekolah yang berbasis pesantren sebagai berikut;

a) Strategi produk, MA Al-Ma'had An-Nur adalah sekolah yang mengintegrasikan kurikulum sekolah formal (kurikulum 2013) dan kurikulum kepesantrenan;

b) Strategi harga, sekolah dengan biaya yang terjangkau bagi semua kalangan

c) Strategi tempat, lokasi sekolah yang strategis mudah diakses dengan kendaraan pribadi dan umum. MA Al-Ma'had An-Nur beralamatkan di kampung Ngrukem, Desa Pendowoharjo, Kecamatan Sewon, Kabupaten Bantul, Daerah Istimewa Yogyakarta. Jarak sekolah ini dari pusat kota Yogyakarta sekitar 8 kilometer, sedangkan dari pusat kota Bantul sekitar 1 kilometer;

d) Strategi promosi, memanfaatkan media promosi yang dimiliki pondok pesantren An-Nur sebagai media promosi MA Al-Ma'had An-Nur, seperti Fanspage, Instagram, Channel Youtube, dan aplikasi Android (Annurngerkem). Sedangkan media komunikasi intensif dengan para pelanggan jasa pendidikan (wali murid/walisantri) memanfaatkan grup whatsapp yang dimiliki oleh asrama-asrama pondok pesantren;

e) Strategi sumber daya manusia (SDM), guru lulusan pesantren serta lulusan strata satu dan sebagaian lulusan strata dua dengan keahlian bidang mata pelajaran masing-masing. Adapun SOP karyawan sekolah dalam melayani siswa adalah S3P (Senyum, Santun, Selesai dan Profesional); 
f) Strategi bukti fisik, menyediakan sarana-prasarana yang baik bagi penunjang dalam kegiatan belajar mengajar, selain itu memanfaatkan sarana prasarana yang dimiliki yayasan pondok pesantren An-Nur sebagai lembaga induk; dan

g) Strategi proses, menawarkan tiga pembinaan yang terkoneksi satu dengan yang lain, meliputi; pembinaan di asrama pondok pesantren, pembinaan di MA Al-Ma'had An-Nur ketika proses kegiatan belajar mengajar di sekolah, dan pembinaan di Madrasah Diniyah An-Nur pada saat proses kegiatan belajar mengajar di MADIN. Pembinaan berlapis, yang dilakukan MA AlMa’had An-Nur dalam rangka mencapai visi, misi serta target sekolah.

2. Pelaksanaan Pemasaran Jasa Pendidikan di MA Al-Ma'had An-Nur, melalui dalam 4 tahapan, adapun tahapannya sebagai berikut; pertama, perencanaan, sebelum memasarkan sekolah, MA Al-Ma'had An-Nur melakukan pemetaan calon pelanggan jasa pendidikan dengan memasukan unsur strategi persaingan (segmentasi, targeting dan positioning); kedua, pengorganisiran, dalam hal ini MA Al-Ma'had An-Nur membentuk kepanitiaan penerimaan peserta baru dengan nama Panitia Penerimaan Peserta didik Baru (P3DB); ketiga; pengarahan dalam rangka menjelaskan tugas dan wewenang panitia penerimaan peserta didik baru; dan keempat, pengawasan untuk memastikan kepanitiaan yang dibentuk berjalan dengan baik.

3. Faktor pendukung pemasaran pendidikan di MA Al-Ma'had An-Nur adalah; pertama, sekolah yang terintegrasi dan interkoneksi antara kurikulum sekolah dan pesantren; kedua, biaya pendidikan yang terjangkau;ketiga, lokasi yang mudah dijangkau kendaraan pribadi dan umum; keempat, memiliki media sendiri dalam promosi dan komunikasi kepada konsumen jasa pendidikan; kelima, memiliki guru yang mumpuni pada mata pelajaran masing-masing; keenam, memiliki sarana dan prasarana untuk menunjang proses KBM; dan ketujuh, menawarkan proses pembinaan berlapis bagi peserta didik guna mencapai visi, misi serta target sekolah. Sedangkan faktor penghambat berjalannya proses pemasaran jasa pendidikan adalah; pertama, integrasi yang belum berjalan secara menyeluruh antara kurikulum sekolah dan kepesantrenan; dan kedua, guru yang memiliki profesi ganda di lembaga 
pendidikan yang dimiliki pondok pesantren An-Nur. Adapun solusi yang ditawarkan peneliti sebagai berikut; pertama, sekolah menyediakan kelas persiapan MA; dan kedua, guru yang memiliki profesi ganda di lembaga pendidikan yang ada di pondok pesantren An-Nur pada dasarnya tidak menjadi faktor penghambat, karena peserta didik yang dihadapi adalah siswa-siswi sekaligus santri/wati dibawah yayasan pondok pesantren An-Nur, asalkan guru tersebut dapat bekarja secara profesional.

\section{Daftar Pustaka}

Arsip MA Al-Ma'had An-Nur 2019

Azra, Azumardi. (1999). Pendidikan Islam: Tradisi dan Modernisasi Menuju Milenium Baru. Jakarta : Logos Wacana Ilmu.

Fandy, Tjiptono. (2008). Strategi Pemasaran. Yogyakarta: Andi.

Kementerian Pendidikan dan Kebudayaan RI. (2016). Direktorat Jenderal Pendidikan Dasar dan Menengah, Direktorat Pembinaan SMP, Laporan Monitoring dan Evaluasi Program Sekolah Berbasis Pesantren. Jakarta: Kemendikdasmen.

Labaso, Syahrial. (2018). "Penerapan Marketing Mix sebagai Pemasaran Jasa Pendidikan di MAN 1 Yogyakarta". Manageria : Jurnal Manajemen Pendidikan Islam, Vol. 3 No. 2, November.

Machali, Imam; Ara Hidayat. (2016). The Handbook of Education Management: Teori dan Praktik Pengeloaan Sekolah/Madrasab di Indonesia. Jakarta: Prenadamedia Group.

Machfoedz, Mahmud. (2005). Pengantar Pemasaran Modern. Yogyakarta: UUP AMP YKPN.

Madjid, Nurcholish. (1997). Bilik-Bilik Pesantren Sebuab Potret Perjalanan. Jakarta: Penerbit Paramadina.

Moleong, L.J. (2013). Metodologi Penelitian Kualitatif, edisi Revisi Bandung: PT Remaja Rosdakarya.

Nizar, Samsul. (2013). Sejarah Sosial dan Dinamika Intelektual. Jakarta: Kencana Prenada Media Grup.

Pasal 3 Undang-Undang No 20 Tahun 2003 Tentang Pendidikan Nasional.

Prastowo, Andi. (2014). Memahami Metode-Metode Penelitian. Yogyakarta: Ar-Ruzz Media.

Soebahar, Abd Halim. (2013). Modernisasi Pesantren; Studi Tranformasi Kepemimpinan Kiai dan Sistem Pendidikan Pesantren Yogyakarta: LKiS 
Surat Keputusan Kepala Madrasah MA Al-Ma'had An-Nur tentang Pembentukan Panitia Penerimaan Peserta Didik Baru, 2019P.

Sugiyono. (2019). Metodologi Penelitian Pendidikan, Pendekatan Kuantitatif, Kualitatif, dan R®D Bandung: Alfabeta, 2019. 